\title{
Nutritional and metabolic parameters of sheep fed with extrused roughage in comparison with corn silage
}

\section{Parâmetros nutricionais e metabólicos de ovinos alimentados com volumoso extrusado em comparação com a silagem de milho}

\author{
Karla Alves Oliveira ${ }^{1}$; Gilberto de Lima Macedo Junior ${ }^{2}$; Simone Pedro da Silva ${ }^{2 *}$; \\ Carolina Moreira Araújo ${ }^{1}$; Laura Ferrari Monteiro Varanis ${ }^{1}$; \\ Luciano Fernandes Sousa ${ }^{3}$
}

\begin{abstract}
The objective of this study was to evaluate the use of extrused roughage on nutritional and metabolic parameters in sheep. Eighteen 3-year-old sheep in metabolic cages were randomly assigned to two treatments: corn silage and extruded roughage. Dry matter intake (DMI) and water intake were calculated as the difference between offered feed and orts left. Ruminal movement was assessed through auscultation of the rumen for five minutes, glycemia and other metabolites through blood collection by jugular venipuncture, and feeding behavior by observation every 5 minutes for 24 hours. DMI per animal, both as a percentage of live weight and in relation to metabolic weight, was higher for animals fed extrused roughage. The extrused roughage treatment also resulted in reduced ruminal movement and higher dry matter digestibility (DMD), glycemia and drinking water intake. Animals fed with extrused roughage reduced the time of rumination and total chewing, thus increasing ingestion, chewing and rumination efficiency. Blood concentrations of glucose and urea were higher in animals fed extrused roughage, while cholesterol concentration was lower. We conclude that the use of extrused roughage promotes improvement in the nutritional parameters of sheep by increasing DMI and DMD, and reducing chewing and rumination times, without causing disorders in energy and protein metabolism.
\end{abstract}

Key words: Extrusion. Nutrition. Ovis Áries. Ruminants.

\section{Resumo}

Objetivou-se, com este estudo, avaliar o efeito da utilização do volumoso extrusado sobre os parâmetros nutricionais e metabólicos em ovinos. Para isso utilizou-se dezoito ovelhas com idade média de 3 (três) anos, alocadas em gaiolas metabólicas, distribuídas em delineamento inteiramente casualizado em dois tratamentos: silagem de milho e volumoso extrusado. O CMS e consumo de água foram calculados pela diferença entre ofertado e sobra. A movimentação ruminal foi obtida através de auscultação do rúmen por cinco minutos, a glicemia e os metabólitos energéticos e proteicos através de coleta de sangue por venopunção jugular, e o comportamento ingestivo por observação a cada 5 minutos durante 24 horas. O CMS quando expresso em porcentagem do peso corporal e em relação ao peso metabólico foi maior

1 Discentes, Curso de Mestrado, Programa de Pós-Graduação em Ciências Veterinárias, Universidade Federal de Uberlândia, UFU, Uberlândia, MG, Brasil. E-mail: karla.alves.oliveira@hotmail.com; carolina.am@hotmail.com; laura ferrari@gmail.com

2 Profs. Drs., UFU, Faculdade de Medicina Veterinária, Programa de Pós-Graduação em Ciências Veterinárias, Uberlândia, MG, Brasil. E-mail: gilbertomacedojr@gmail.com; simone.silva@ufu.br

3 Prof. Dr., Departamento de Zootecnia da Escola de Medicina Veterinária e Zootecnia, Universidade Federal de Tocantins, UFT, Araguaína, TO, Brasil. E-mail: luciano.sousa@mail.uft.edu.br

* Author for correspondence 
para o tratamento com volumoso extrusado em todas as unidades estudadas, o que se deve a melhor digestibilidade da matéria seca da ração. A movimentação ruminal foi menor e a digestibilidade da matéria seca (DMS), glicemia e o consumo de água bebida maior para o tratamento com o volumoso extrusado. Os animais alimentados com o volumoso extrusado reduziram o tempo de ruminação e mastigação total, consequentemente aumentaram a eficiência de ingestão, ruminação e mastigação total. A concentração sanguínea de glicose e ureia foi maior para o tratamento com o volumoso extrusado, enquanto a concentração do colesterol foi menor. Conclui-se que o uso do volumoso extrusado promove melhoria nos parâmetros nutricionais de ovinos, aumentando CMS e DMS, e reduzindo tempos de ruminação de mastigação, sem provocar transtornos no metabolismo energético e proteico.

Palavras-chave: Extrusão. Nutrição. Ovis Áries. Ruminantes.

\section{Introduction}

In animal production systems, feed represents the largest fraction of total production cost; therefore, in order to reduce expenses, it is of great importance that the animals be given balanced diets and that nutrients can be better absorbed by the animals. Certain feed-processing techniques can be used to improve the nutrient availability in terms of nutrient content and absorption, with responses in animal production and intake (WHITLOCK et al., 2002). One process is feed extrusion, which improves the digestibility of starch, proteins and fibers, and is beneficial to ruminant animals.

The extrusion process consists of HTST (High Temperature Short Time) heat treatments. The combination of heat, humidity and mechanical work deeply modifies the raw materials, providing new formats and structures with different functional and nutritional characteristics (GUERREIRO, 2007). This process causes physical and chemical changes in nutrients, such as increased digestibility due to protein denaturation and starch gelatinization. Anti-nutritional factors are destroyed and growth inhibitors are inactivated during this process. Extruded feeds may have a low microorganism count and absence of pathogens (GUERREIRO, 2007).

A key feature of the extruded ration for ruminant animals is the inclusion of fiber in its composition, which is a nutritive component of great importance for the proper functioning of the rumen. A change that can occur in the fiber during an extrusion is to increase digestibility. This effect is caused by the rupture of carbohydrate and proteins in the fiber, resulting in a greater fragmentation (RAMACHANDRA; THEJASWINI, 2015) that makes it more degradable and consequently improves its total digestibility.

By evaluating the metabolic profile of an animal, it is possible to diagnose biochemical alterations that decrease production or are responsible for potentially fatal diseases (CONTRERAS, 2000). Energy and protein metabolites are often used to evaluate ruminants' nutritional profiles. The most commonly used energy metabolites - glucose, betahydroxybutyrate, free fatty acids, cholesterol and triglycerides- help to evaluate the fermentation of carbohydrates in the rumen, especially with regard to the fibrous ration fraction. The most commonly used protein metabolites are total proteins, albumin and urea; these help to identify if the amount of protein offered in the diet is adequate, since it is the nutritive component with the highest cost in the diet.

Considering that extruded roughage can cause increased digestibility of fiber and protein and that this promotes an increase in animal performance, it is important to study the effects that using this product in ruminant feed has on nutritional and metabolic parameters, since the reduced particle size of this feed can cause changes in animals' intake, digestibility, feeding behavior and metabolism. The objective of this study was to evaluate the effects of extruded roughage on nutritional and metabolic parameters in sheep. 


\section{Material and Methods}

The experiment was conducted in June and July of 2016 in the Sheep Section of Capim Branco Farm at the Faculty of Veterinary Medicine of the Universidade Federal de Uberlândia (UFU), located in Uberlândia, Minas Gerais, Brazil. The area is located in a region where a Cwa climate (Köppen standards) predominates, with an annual rainfall of $1584 \mathrm{~mm}$ and average annual temperature of 22.3 ${ }^{\circ} \mathrm{C}$.

Eighteen adult female sheep (Santa Inês breed) were used; they were not pregnant, had a mean body weight of $42 \mathrm{~kg}$, and approximately 3-year-old. The animals were maintained in metabolic cages equipped with feeder, water fountain, salt shaker, slatted floor and a separation artifact of feces and urine. The experiment was divided into three periods of 10 days each, with 5 days of adaptation to diet and 5 days of collection (orts left of feed, water, feces and urine).

Two diets were evaluated, one with corn silage and the other with extruded roughage (Foragge ${ }^{\mathbb{R}}$, Nutratta Company, Itumbiara, GO, Brazil, Table 1). Foragge ${ }^{\circledR}$ is a product that resembles corn silage in the extruded form, and is composed of the aerial part of the sugar cane and characterized by easy feed handling. Foragge ${ }^{\circledR}$ contains starch, urea and minerals in addition.

Table 1. Bromatological composition of Foragge ${ }^{\circledR *}$ and corn silage.

\begin{tabular}{lcc}
\hline Nutrient & Foragge $^{\circledR}(\%)$ & Corn Silage (\%) \\
\hline Dry Matter & 92.62 & 30.86 \\
Crude Protein & 9.81 & 7.89 \\
Ether Extract & 1.50 & 2.72 \\
Mineral Matter & 6.55 & xxx \\
Neutral Detergent Fiber & 32.27 & 40.00 \\
Acid Detergent Fiber & 20.98 & 23.45 \\
Non-Fibrous Carbohydrates & 49.87 & xxx \\
Total Digestible Nutrients & 71.34 & 68.39 \\
\hline
\end{tabular}

* Values supplied by the Nutratta Company, Itumbiara, GO, Brazil.

Ration orts were measured daily and whenever there was no excess, the quantity offered was increased by $10 \%$ until reaching a ration leftover equivalent to $10 \%$ of the amount offered. DMI (dry matter intake) of the feed was calculated as the difference between the offered amount and the orts left.

Feces produced by the animals were collected and weighed and the dry matter (DM) was determined, making it possible to calculate dry matter digestibility (DMD) of feed using the following formula:

$$
\mathrm{DMD}=\frac{\mathrm{DMI}-\mathrm{FPDM} \times 100}{\mathrm{DMI}}
$$

Where:

$\mathrm{DMI}=$ dry matter intake $\left(\mathrm{kg} \mathrm{day}^{-1}\right)$;

FPDM $=$ feces production in dry matter $\left(\mathrm{kg} \mathrm{day}^{-1}\right)$.

Fecal scores were determined daily during the collection period using the scale proposed by Gomes (2008), where at level one (1) the feces are dry and dull; at level two (2) the feces are normal; at level three (3) the feces are slightly softened; at level four (4) the feces are softened, losing their shape and glued together (grape bunches); at level five (5) the feces are softened and unformed (swine feces); and at level six (6) the feces are diarrheal.

Six liters of water per animal were provided each morning in plastic buckets, with additional water 
provided in the afternoon when necessary (always noting the quantity when supplied). Water leftovers were measured the following day. Water intake from the bucket was calculated based on the difference between the offered and the leftover water, and total water intake was calculated by adding water intake from the bucket to the water contained in ingested feed. The water content contained in the feed was obtained by the equation: 100 - DM content of the food.

Ruminal movement was evaluated one time in each collection period by auscultation with a stethoscope for five minutes (RADOSTITS et al., 2007).

To measure feeding behavior, animals were visually observed by trained people for twenty four hours one time during the collection. Observers worked in a relay system arranged in a way not to disturb the animals. At night, the environment received artificial light; the lights were kept on for five days before the evaluation to promote adaptation of the animals. It was noted every five minutes if the animals were feeding or drinking water separately (ING), were ruminating (RUM), or were resting (REST), according to the methodology proposed by Fischer et al. (1998). Activity was calculated in minutes per day, assuming that within five minutes of each observation, the animal remained in the same activity. Total time spent in chewing (CHEW) was determined by adding time spent on ingestion (ING) and rumination (RUM). Efficiency of intake (EIng), chewing (EChew) and rumination (ERum) were obtained following Polli et al. (1996), according to the equations: EIng $\left(\mathrm{g} \mathrm{min}^{-1}\right)=\mathrm{DMI} /$ Tint, EChew $\left(\mathrm{g} \mathrm{min}^{-1}\right)=\mathrm{DMI} /$ Tchew, and ERum $\left(\mathrm{g} \min ^{-1}\right)=\mathrm{DMI} /$ Trum; where DMI is dry matter intake ( $\mathrm{g}$ DM day ${ }^{-1}$ ), Ting is ingestion time (min day $\left.^{-1}\right)$, Tchew is chewing time $\left(\mathrm{min}_{\mathrm{day}}{ }^{-1}\right)$ and Trum is rumination time $\left(\min\right.$ day $\left.^{-1}\right)$.

Blood for glycemic evaluation and determination of biochemical components was collected by jugular venipuncture using Vacutainer ${ }^{\circledR}$ (BD Company,
United States), tubes without anticoagulant, on three separate days at the beginning, middle and end of the collection period. All blood collections were performed in the morning before the first feeding. Blood samples were centrifuged at $3000 \mathrm{rpm}$ for 10 minutes, then the serum was separated into aliquots, stored in microtubes and kept in a freezer at -5 ${ }^{\circ} \mathrm{C}$ for later laboratory analysis. The biochemical components for determination of energy metabolism were: triglycerides, cholesterol and VLDL (very low density lipoprotein). The components for determination of protein metabolism were: total protein, albumin, uric acid, urea, creatinine and albumin:globulin ratio. All samples were processed in an automated biochemical analyzer (Bioplus ${ }^{\circledR}$ 2000, Bioplus Company, Barueri, SP, Brazil) using commercial kit GT Lab ${ }^{\circledR}$ (GT Laboratory Company, Santa Fe, Argentina).

A completely randomized design with two treatments and nine replications was used. The means of treatments were evaluated by Tukey's test at a significance level of $\alpha=0.05$. Fecal score data were analyzed by non-parametric statistics using the Kruskal and Wallis (1952) and Conover (1998) tests. Data were subjected to analysis of variance by the proc GLM (version 9.0, SAS Institute Inc., Cary, NC, USA), and the mathematical model used:

$$
Y i j=\mu+T j+\varepsilon i j
$$

Yij is the dependent variable; $\mu$ the general average of observations; $\mathrm{Tj}$ effect of the $\mathrm{j}$-th feed treatment and eij the residual random error.

\section{Results and Discussion}

Animals that received extruded roughage had higher dry matter intake (DMI) both in $\mathrm{kg}$ day $^{-1}$ and relative to body weight $(\% \mathrm{BW})$ and metabolic weight $\left(\mathrm{BW}^{0.75}\right)(\mathrm{p}<0.05)$; Table 2$)$. According to the NRC (2007), the mean DMI for adult sheep in maintenance is approximately $1.83 \% \mathrm{BW}$. The animals that received extruded roughage in this study had DMI (\%BW) $51.8 \%$ above the average 
value estimated by the NRC for this animal category. The higher intake for animals receiving extruded roughage may be due to the extrusion process of the roughage, which causes a reduction in feed particle size. The product used in this study has an average fiber size of $2 \mathrm{~mm}$, which may have caused an increase in the passage rate of the feed and a consequent increase in intake. Other studies have demonstrated that the particle size of forage changes feed intake (MOHARRERY, 2010) and the average retention time of the digesta (SEO et al., 2009; WORRELL et al., 1986).

Table 2. Dry matter intake (DMI) expressed in $\mathrm{kg} \mathrm{day}^{-1}$ and in relation to body weight (\%BW) and metabolic weight $\left(\mathrm{BW}^{0.75}\right)$, and dry matter digestibility (DMD) in sheep fed with corn silage or extruded roughage.

\begin{tabular}{lcccc}
\hline Treatment & DMI $\left(\mathrm{kg} \mathrm{day}^{-1}\right)$ & DMI $(\% \mathrm{BW})$ & DMI $\left(\mathrm{BW}^{0,75}\right)$ & DMD \\
\hline Extruded roughage & $2.08 \mathrm{~A}$ & $4.60 \mathrm{~A}$ & $119.22 \mathrm{~A}$ & $71.30 \mathrm{~A}$ \\
Corn silage & $1.11 \mathrm{~B}$ & $2.42 \mathrm{~B}$ & $63.11 \mathrm{~B}$ & $63.49 \mathrm{~B}$ \\
\hline Mean & 1.54 & 3.39 & 88.05 & 66.96 \\
CV & 19.56 & 13.35 & 14.40 & 10.71 \\
\hline
\end{tabular}

Values labeled A were different $(\mathrm{p}<0.05)$ than the corresponding values labeled B, by Tukey's test; CV: coefficient of variation.

Dry matter digestibility was higher for animals that received the extruded roughage (Table 2), which is likely due to the extrusion process causing changes in the nutrient matrix (starch, proteins and fibers) that make them more digestible. According to Ramachandra and Thejaswini (2015), digestible fiber increases during the extrusion process due to the rupture of connections between the carbohydrates and proteins in the fiber, resulting in a greater fragmentation of the fiber.

Water intake (drinking or free water) and the water intake relative to DMI were higher for animals fed extruded roughage (Table 3 ). In ruminant animals there are three main sources of water: (1) drinking or free water, which makes up 70 to $97 \%$ of the water ingested; (2) feed water (colloidal), which is the fraction bound to the feed; and (3) the metabolic water that is formed during the processing of nutrients in the animal's body (ANDRIGUETTO et al., 1986). Since the amount of water drunk is directly related to the dry matter content of feed, the animals fed with extruded roughage containing a higher DM content than the corn silage had a higher intake of drinking water than the animals that consumed corn silage. This agrees with the observation by Kume et al. (2010) that voluntary water intake was higher with rations that contained more dry matter.

Table 3. Water intake $\left(\mathrm{IH}_{2} \mathrm{O}\right)$, total water intake (Total $\left.\mathrm{IH}_{2} \mathrm{O}\right)$ and water intake expressed in relation to dry matter intake $\left(\mathrm{IH}_{2} \mathrm{O} / \mathrm{DMI}\right)$ in sheep fed with corn silage or extruded roughage.

\begin{tabular}{lccc}
\hline Treatment & $\mathrm{IH}_{2} \mathrm{O}(\mathrm{L})$ & Total $\mathrm{IH}_{2} \mathrm{O}(\mathrm{L})$ & $\mathrm{IH}_{2} \mathrm{O} / \mathrm{DMI}\left(\mathrm{L} \mathrm{kg}^{-1}\right)$ \\
\hline Extruded roughage & $3.22 \mathrm{~A}$ & 3.22 & $1.61 \mathrm{~A}$ \\
Corn silage & $1.20 \mathrm{~B}$ & 3.53 & $1.09 \mathrm{~B}$ \\
\hline Mean & 2.60 & 3.39 & 1.32 \\
$\mathrm{CV}$ & 27.95 & 18.85 & 36.00 \\
\hline
\end{tabular}

Values labeled A were different $(\mathrm{p}<0.05)$ than the corresponding values labeled B, by Tukey's test; CV: coefficient of variation. 
Animals fed extruded roughage had higher fecal production (FP) when expressed in natural matter and dry matter, and higher fecal score values (Table 4). Fecal score (shape and consistency) is an important indicator of changes in the gastrointestinal tract and their associated implications for animal health and performance (FERREIRA et al., 2013). According to the scale proposed by Gomes (2008), which ranges from 1 to 6 , lower values refer to drier feces and higher values to softer feces. In this study, animals fed extruded roughage with a mean particle size of $2.0 \mathrm{~mm}$ had softer feces when compared with animals fed corn silage. Fecal score and fecal consistency are directly related to the physically-effective NDF dietary content (NDFpe) (IRELAND-PERRY; STALLINGS, 1993; SILVA et al., 2012). Since extruded roughage has a lower NDF content and lower fiber effectiveness when compared with corn silage, this may have caused an increase in the passage rate of the digesta along the gastrointestinal tract and the production of feces with a softer consistency.

Table 4. Fecal production expressed in natural matter (FPNM), dry matter (FPDM), dry matter content in feces (DMF) and fecal score (FS) in sheep fed with corn silage and extruded roughage.

\begin{tabular}{lcccc}
\hline Treatment & FPNM $(\mathrm{kg})$ & FPDM $(\mathrm{g})$ & DMF $(\%)$ & FS* \\
\hline Extruded roughage & $1.798 \mathrm{~A}$ & $551.67 \mathrm{~A}$ & 31.74 & $3.2 \mathrm{~A}$ \\
Corn silage & $1.286 \mathrm{~B}$ & $404.33 \mathrm{~B}$ & 32.81 & $2.7 \mathrm{~B}$ \\
\hline Mean & 1.514 & 469.81 & 32.34 & 2.9 \\
CV & 36.64 & 11.64 & 15.19 & --- \\
\hline
\end{tabular}

Values labeled A were different $(\mathrm{p}<0.05)$ than the corresponding values labeled B, by Tukey's test; CV: coefficient of variation; *fecal score (FS) scale proposed by Gomes (2008), where at level one (1) the feces are dry and dull; at level two (2) the feces are normal; at level three (3) the feces are slightly softened; at level four (4) the feces are softened, losing their shape and glued together (grape bunches); at level five (5) the feces are softened and unformed (swine feces); and at level six (6) the feces are diarrheal.

Animals fed extruded roughage spent less time in rumination and total chewing and, therefore, more time resting when compared with the animals fed corn silage ( $p \mathrm{p}<0.05$; Table 5). The decreased fiber particle size resulting from the extrusion process has two main effects. First, it limits chewing, decreasing its effectiveness in maintaining ruminal $\mathrm{pH}$, and second, it raises the intake potential of these feeds since the volume occupied by the ground food will be lower than that of unprocessed food, thus increasing intake (ZANINE; MACEDO JÚNIOR, 2006). Many studies have demonstrated the effect of reduced particle size on chewing time (HADJIGEORGIOU, 2003; MERTENS, 1997). However, it should be noted that the reduction in rumination and chewing time in animals fed with extruded roughage can lead to a decrease in saliva production, which causes problems of acidosis in animals submitted to diets with higher concentrate content.
Animals fed extruded roughage had higher DMI in relation to rumination and total chewing. According to Van Soest (1994), rumination time is influenced by the type of diet and appears to be proportional to the cell wall content of the roughage. Concentrated feeds and finely crushed, pelleted or extruded roughage reduce rumination time, while roughage with high cell wall content tends to increase rumination time. Increased dry matter intake tends to reduce rumination time per gram of feed. The efficiency of rumination and total chewing observed in this study was higher when the animal ingested extruded roughage compared with corn silage. However, this is not necessarily advantageous, since less rumination may have deleterious consequences for the physiology of the ruminal environment. Therefore, it is important to emphasize that more studies on roughage in the extruded form, mainly with animals submitted to 
diets with higher concentrate content, are necessary in order to verify the effect of this roughage on the maintenance of $\mathrm{pH}$ conditions in the ruminal environment.

Table 5. Feeding behavior, ingestion, rumination and total chewing efficiency $\left(\mathrm{g} \mathrm{min} \mathrm{m}^{-1}\right)$ in sheep fed with corn silage or extruded roughage.

\begin{tabular}{lcccc}
\hline Treatment & ING $(\mathrm{min})$ & RUM $(\mathrm{min})$ & REST $(\mathrm{min})$ & CHEW $(\mathrm{min})$ \\
\hline Extruded roughage & 278.87 & $94.37 \mathrm{~B}$ & $1128.75 \mathrm{~A}$ & $335.00 \mathrm{~B}$ \\
Corn silage & 327.16 & $528.16 \mathrm{~A}$ & $584.66 \mathrm{~B}$ & $855.33 \mathrm{~A}$ \\
\hline Mean & 305.70 & 335.37 & 826.48 & 624.07 \\
CV & 29.79 & 24.17 & 18.50 & 21.62 \\
\hline Treatment & ING $(\%)$ & RUM $(\%)$ & REST $(\%)$ & CHEW $(\%)$ \\
\hline Extruded roughage & 17.54 & $6.60 \mathrm{~B}$ & $78.38 \mathrm{~A}$ & $24.02 \mathrm{~B}$ \\
Corn silage & 22.71 & $36.67 \mathrm{~A}$ & $40.60 \mathrm{~B}$ & $59.39 \mathrm{~A}$ \\
\hline Mean & 20.41 & 23.31 & 57.39 & 43.67 \\
CV & 35.32 & 24.12 & 18.50 & 20.82 \\
\hline Treatment & EIng $\left(\mathrm{g} \mathrm{min}\right.$ min $\left.^{-1}\right)$ & ERum $\left(\mathrm{g} \mathrm{min} \mathrm{m}^{-1}\right)$ & EChew $\left(\mathrm{g} \mathrm{min}^{-1}\right)$ & \\
\hline Extruded roughage & $13.07 \mathrm{~A}$ & $26.89 \mathrm{~A}$ & $8.85 \mathrm{~A}$ & \\
Corn silage & $3.65 \mathrm{~B}$ & $2.15 \mathrm{~B}$ & $1.33 \mathrm{~B}$ & \\
\hline Mean & 7.84 & 13.15 & 4.67 & \\
CV & 35.44 & 32.06 & 33.44 & \\
\hline
\end{tabular}

ING: ingestion; RUM: rumination; REST: resting; CHEW: total chewing; EIng: ingestion efficiency; ERum: rumination efficiency; EChew: chewing efficiency; CV: coefficient of variation; values labeled A were different $(\mathrm{p}<0.05)$ than the corresponding values labeled B, by Tukey's test.

Lower ruminal movement was observed in the animals that received extruded roughage when compared with the animals that received corn silage $(p<0.05$; Table 6$)$, which is due to the lower fiber effectiveness caused by small particle size $(2.0 \mathrm{~mm})$ of the extruded roughage, as well as a higher content of NFC and lower NDF. These characteristics may cause reduction in ruminal $\mathrm{pH}$ and decrease in ruminal motility (NOCEK et al., 1984). Despite the reduction in ruminal movements in the animals fed with extruded roughage, the values observed in the present study allow us to infer that there were no digestive problems in the animals because ruminal movements were still within the 1-2 movements per minute range of sheep in thermal comfort, as found by Faria (2010).

Table 6. Glycemia and ruminal movements in sheep fed with corn silage or extruded roughage.

\begin{tabular}{lcc}
\hline Treatment & Glycemia $\left(\mathrm{mg} \mathrm{dL}^{-1}\right)$ & Ruminal mov. $\left(\mathrm{mov} 5 \mathrm{~min}^{-1}\right)$ \\
\hline Extruded roughage & $49.33 \mathrm{~A}$ & $6.12 \mathrm{~B}$ \\
Corn silage & $42.16 \mathrm{~B}$ & $7.40 \mathrm{~A}$ \\
\hline Mean & 45.35 & 6.83 \\
CV & 16.04 & 15.21 \\
\hline
\end{tabular}

Ruminal mov.: ruminal movements; CV: coefficient of variation; values labeled A were different $(\mathrm{p}<0.05)$ than the corresponding values labeled B, by Tukey's test.

Animals fed with extruded roughage had higher blood glucose concentrations than those fed with corn silage $(p<0.05$; Table 6$)$. Extruded roughage contains a higher concentration of starch with higher digestibility. This leads to higher rumen production of propionate, which is a precursor of 
glucose in ruminants. In addition, the animals fed with this product had higher dry matter intake and digestibility.

There was no effect of roughage type on the concentrations of energy metabolites, with the exception of cholesterol (Table 7). Sheep fed with corn silage had a higher blood cholesterol concentration when compared with those fed extruded roughage $(\mathrm{p}<0.05)$. Corn silage contains on average $40 \% \mathrm{NDF}$, as opposed to about $32 \%$ in extruded roughage, leading to increased NDF intake and higher acetic acid production in the rumen, which is the main fat precursor in ruminants and may have generated increased blood cholesterol concentration in these animals.

Table 7. Blood concentration ( $\mathrm{mg} \mathrm{dL}^{-1}$ ) of energetic and protein metabolites in sheep fed with different types of roughage.

\begin{tabular}{lccccc}
\hline Treatment & Cholesterol & Triglycerides & VLDL & Total Protein & Albumin \\
\hline Extruded roughage & $29.50 \mathrm{~B}$ & 12.70 & 2.54 & 7.96 & 4.30 \\
Corn silage & $36.26 \mathrm{~A}$ & 18.66 & 3.73 & 8.47 & 4.55 \\
\hline Mean & 33.25 & 16.01 & 3.20 & 8.24 & 4.44 \\
$\mathrm{CV}$ & 16.91 & 20.40 & 16.33 & 15.72 & 11.71 \\
$\mathrm{RV} *$ & $52-76$ & $17.6-24.0$ & & $6.0-7.9$ & $2.4-3.0$ \\
\hline Treatment & Uric Acid & Urea & Creatinine & Globulin & $\mathrm{A}: \mathrm{G}$ \\
\hline Extruded roughage & 0.28 & $38.95 \mathrm{~A}$ & 1.02 & 3.65 & 1.53 \\
Corn silage & 0.32 & $24.89 \mathrm{~B}$ & 1.08 & 3.91 & 1.55 \\
\hline Mean & 0.30 & 31.14 & 1.05 & 3.79 & 1.54 \\
CV & 7.51 & 19.13 & 15.11 & 18.64 & 19.80 \\
$\mathrm{RV} *$ & $0.0-1.9$ & $17.1-42.8$ & $1.2-1.9$ & $3.5-5.7$ & $0.42-0.76$ \\
\hline
\end{tabular}

$\mathrm{CV}$ : coefficient of variation; values labeled A were different $(\mathrm{p}<0.05)$ than the corresponding values labeled B, by Tukey's test; *RV: Reference values according to Kaneko et al. (2008); VLDL: very low density lipoprotein; A:G: albumin:globulin ratio.

There was no effect of roughage type on concentrations of protein metabolites, with the exception of urea (Table 7). Total protein and albumin concentrations were slightly above the reference values for ovine species, and the creatinine was below the reference value. However, despite these changes, no nutritional problems were identified in the animals.

Animals that received extruded roughage had higher urea concentration than those that received corn silage $(p<0.05$; Table 7$)$. The blood concentration of urea is directly related to the protein content of the ration and may indicate an excess or deficiency of this nutrient in the diet (GONZÁLEZ et al., 2000). The extrusion process to which the roughage in this study was subjected may have caused increased protein digestibility in the rumen and greater release of ammonia $\left(\mathrm{NH}_{3}\right)$. If there were insufficient fermentable energy to form the microbial protein, excess $\mathrm{NH}_{3}$ would be converted to urea in the liver through the urea cycle, which would be identified through increased concentration of this compound in the bloodstream (WITTER, 2000).

\section{Conclusions}

Sheep fed with extruded roughage in place of corn silage show improved nutritional parameters such as an increase in dry matter digestibility and a reduction in chewing and rumination time, without accompanying dysfunctions in energy and protein metabolism. 


\section{References}

ANDRIGUETTO, J. M.; PERLY, L.; MINARDI, I.; GEMAEL, A.; FLEMMING, J. S.; SOUZA, G. A.; BONA FILHO, A. Nutrição animal. $3^{\text {th }}$ ed. São Paulo: Nobel, 1986. 425 p.

CONOVER, W. J. Practical nonparametric statistics. New York: Wiley, 1998. 592. p.

CONTRERAS, P. Indicadores do metabolismo proteico utilizados nos perfis metabólicos de rebanhos. In: GONZÁlEZ, F. H. D.; BARCELLOS, J.; PATIÑO, H. O.; RIBEIRO, L. A. (Ed.). Perfil metabólico em ruminantes: seu uso em nutrição e doenças nutricionais. Porto Alegre: Gráfica da Universidade Federal do Rio Grande do Sul, 2000. p. 23-30.

FARIA, W. G. Aspectos fisiológicos de ovelhas Santa Inês alimentadas com distintas dietas durante dois periodos climáticos em Pedro Leopoldo - MG. 2010. Dissertação (Mestrado em Zootecnia) - Universidade Federal de Minas Gerais, Belo Horizonte.

FERREIRA, S. F.; GUIMARÃES, T. P.; MOREIRA, K. K. G.; ALVES, V. A.; LEMOS, B. J. M.; SOUZA, F. M. Caracterização fecal de bovinos. Revista Científica Eletrônica de Medicina Veterinária, Garça, v. 20, n. 1, p. 1-22, 2013.

FISCHER, V.; DESWYSEN, A. G.; DÈSPRES, L.; DUTILLEUL, P.; LOBATO, J. F. P. Padrões nectemerais do comportamento ingestivo de ovinos. Revista Brasileira de Zootecnia, Viçosa, MG, v. 27, n. 2, p. 362-369, 1998.

GOMES, S. P. Tamanho de partícula do volumoso e frequência de alimentação sobre aspectos nutricionais $e$ do metabolismo energético em ovinos. 2008. Tese (Doutorado em Zootecnia) - Escola de Veterinária, Universidade Federal de Minas Gerais, Belo Horizonte.

GONZÁlEZ, F. H. D.; BARCELLOS, J.; PATIÑO, H. O.; RIBEIRO, L. A. Perfil metabólico em ruminantes: seu uso em nutrição e doenças nutricionais. Porto Alegre: Gráfica Universidade Federal do Rio Grande do Sul, 2000. 108 p.

GUERREIRO, L. Produtos extrusados para consumo humano, animal e industrial. Rio de Janeiro: Rede de Tecnologia do Rio de Janeiro - REDETEC, 2007. 24 p. Disponível em: <http://sbrt.ibict.br/dossie-tecnico/ downloadsDT/MTcy>. Acesso em: 21 abr. 2016.

HADJIGEORGIOU, I. E.; GORDON, I. J.; MILNE, J. A. Intake, digestion and selection of roughage with different staple lengths by sheep and goats. Small Ruminant Research, Amsterdam, v. 47, n. 2, p. 117-132, 2003.

IRELAND-PERRY, R. L.; STALLINGS, C. C. Fecal consistency as related to dietary composition in lactating holstein cows. Journal of Dairy Science, Savoy, v. 76, n. 4, p. 1074-1082, 1993.

KANEKO, J. J.; HARVEY, J. W.; BRUSS, M. L. Clinical biochemistry of domestic animals. $6^{\text {th }}$ ed. San Diego: Academic Press, 2008. 916 p.

KRUSKAL, W. H.; WALLIS, W. A. Use of ranks in one-criterion variance analysis. Journal of the American Statistical Association, New York, v. 47, n. 260, p. 583621, 1952.

KUME, S.; NONAKA, K.; OSHITA, T.; KOZAKAI, T. Evaluation of drinking water intake, feed water intake and total water intake in dry and lactating cows fed silages. Livestock Science, v. 128, n. 1-3, p. 46-51, 2010.

MERTENS, D. R. Creating a system for meeting the fiber requirements of dairy cows. Journal of Dairy Science, Savoy, v. 80, n. 7, p. 1463-1481, 1997.

MOHARRERY, A. Effect of particle size of forage in the dairy ration on feed intake,production parameters and quantification of manure index. Asian-Australian Journal of Animal Science, Seoul, v. 23, n. 4, p. 483-490, 2010.

NATIONAL RESEARCH COUNCIL - NRC. Nutrient requirements of small ruminants: sheep, goats, cervids, and new world camelids. Washington: National Academy Press, 2007. 384 p.

NOCEK, J. E.; HEALD, C. W.; POLAN, C. E. Influence of ration of physical form and nitrogen availability on ruminal morphology of growing bull calves. Journal of Dairy Science, Champaign, v. 67, n. 2, p. 334-343, 1984.

POLLI, V. A.; RESTLE, J.; SENNA, D. B.; ROSA, C. E.; AGUIRRE, L. F.; SILVA, J. da. Aspectos relativos à ruminação de bovinos e bubalinos em regime de confinamento. Revista Brasileira de Zootecnia, Viçosa, MG, v. 25, n. 5, p. 987-993, 1996.

RADOSTITS, O. M.; GAY, C. C.; BLOOD, D. C.; HINCHCLIFF, K. W. Veterinary medicine: a textbook of the diseases of cattle, horses, sheep, pigs, and goats. $10^{\text {th }}$ ed. Philadelphia: W.B. Saunders, 2007. 2180 p.

RAMACHANDRA, H. G.; THEJASWINI, M. L. Extrusion technology: a novel method of food processing. International Journal of Innovative Science, Engineering \& Technology, Srivilliputtur, v. 2, n. 4, p. 358-369, 2015.

SEO, S.; LANZAS, C.; TEDESCHI, L. O.; PELL, A. N.; FOX, D. G. Development of a mechanistic model to represent the dynamics of particle flow out of the rumen and to predict rate of passage of forage particles in dairy cattle. Journal of Dairy Science, Savoy, v. 92, n. 8, p. 3981-4000, 2009. 
SILVA, H. L.; FRANÇA, A. F. S.; FERREIRA, F. G. C.; FERNANDES, É. S.; LANDIM, A.; CARVALHO, E. R. Indicadores fecais de bovinos nelore alimentados com dietas de alta proporção de concentrado. Ciência Animal Brasileira, Goiânia, v. 13, n. 2, p. 145-156, 2012.

VAN SOEST, P. J. Nutritional ecology of the ruminant. $2^{\text {th }}$ ed. Ithaca: Comstock, 1994. $476 \mathrm{p}$.

WHITLOCK, L. A.; SCHINGOETHE, D. J.; HIPPEN, A. R.; KALSCHEUR, K. F.; BAER, R. J.; RAMASWAMY, N.; KASPERSON, K. M. Fish oil and extruded soilbeans fed in combination increase conjugated linoleic acidsin milk of dairy cows more than when fed separately. Journal of Dairy Science, Savoy, v. 85, n. 1, p. 234-243, 2002.
WITTER, F. Diagnóstico dos desequilíbrios metabólicos de energia em rebanhos bovinos. In: GONZÁLEZ, F. H. D.; BARCELlOS, J.; PATIÑO, H. O.; RIBEIRO, L. A. Perfil metabólico em ruminantes: seu uso em nutrição e doenças nutricionais. Porto Alegre: Gráfica Universidade Federal do Rio Grande do Sul, 2000. p. 9-30.

WORRELL, M. A.; CHTON, D. C.; STRONP, W. W.; NICHOLS, J. T. Effect of harvest date on meadow hay quality. I. Nutritional attributes, voluntary intake and rate of passage in growing cattle. Journal of Animal Science, Champaign, v. 63, n. 5, p. 1527-1537, 1986.

ZANINE, A.; MACEDO JÚNIOR, G. L. Importância do consumo da fibra para nutrição de ruminantes. Revista Eletrônica de Veterinária, Garça, v. 2, n. 4, p. 1-11, 2006. 